\section{Two Deciduous Human Molars from the Early Pleistocene Deposits of Barranco León (Orce, Spain)}

\section{Francesc Ribot, Luis Gibert, Carles Ferràndez-Cañadell, Enrique García Olivares, Florentina Sánchez, and María Lería}

Museo de Prehistoria y Paleontología José Gibert, Calle las Tiendas, s/n.18858-Orce, Spain/Departament de Geoquímica, Petrologia i Prospecció Geològica, Facultat de Geologia, Universitat de Barcelona, Martí Franquès s/n, 08028 Barcelona, Spain (lgibert@ub.edu)/Departament d'Estratigrafia, Paleontologia i Geociències Marines, Facultat de Geologia, Universitat de Barcelona, Martí Franquès s/n, 08028 Barcelona, Spain/Departamento de Bioquímica y Biología Molecular e Inmunología, Facultad de Medicina, Universidad de Granada, 18012-Granada, Spain/Museo de Prehistoria y Paleontología José Gibert, Calle las Tiendas, s/n.18858-Orce, Spain/Departament de Dibuix, Facultat de Belles Arts, Universitat de Barcelona, Pau Gargallo, 4, 08028 Barcelona, Spain. This paper was submitted $12 \mathrm{X} 13$, accepted $17 \mathrm{VII}$ 14, and electronically published 27 I 15.

Recently Toro-Moyano et al. (2013) reported a deciduous tooth from Barranco León (Spain; BL02-J54-100) and claimed it to be the oldest human fossil in Europe. In that paper, the authors suggest that a previously reported human molar fragment from the same site (BL5-0) was not human but a deciduous molar of Hippopotamus found out of stratigraphic context. Here, we show the stratigraphic and spatial position of BL5-0, and we separate it from deciduous teeth of Hippopotamus. We conclude that two human deciduous molars have been discovered at the Barranco León site. Both teeth were found 9 meters apart, have a similar size, are heavily worn on the occlusal surface, have a nearly identical interstitial contact facet, and in both cases the roots are practically missing due to resorption. These similarities and the proximity of the finds suggest that both molars probably belonged to the same individual.

\section{Introduction}

With a continuous sedimentary record and archaeological sites at different stratigraphic heights, the Orce region of southern Spain is one of the candidate localities to uncover early humans in the European Pleistocene (Scott and Gibert 2009). The Orce sites have yielded Early Pleistocene Oldowan

(C) 2015 by The Wenner-Gren Foundation for Anthropological Research. All rights reserved. 0011-3204/2015/5601-0007\$10.00. DOI: 10.1086/ 679615 tools at the sites of Barranco León and Fuentenueva 3 (Gibert et al. 1998b), and fragmentary human remains at Barranco León and at the stratigraphically lower site of Venta Micenathe latter have been a matter of dispute, being supported by some authors (e.g., Aguirre 2008; Borja et al. 1997; Campillo et al. 2003, 2006; Coppens 1992; Gibert and Palmqvist 1995; Gibert et al. 1989a, 1989b, 1998a, 2006a, 2006b; Lowenstein, Borja, and García-Olivares 1999; Martínez-Navarro 1996; Sánchez et al. 1999; Tobias 1998; Torres, Borja, and GarcíaOlivares 2002) and rejected by others (e.g., Martínez-Navarro 2002; Moyà and Agustí 1989; Moyà and Köhler 1997; Palmqvist et al. 2005).

Recently Toro-Moyano et al. (2013) reported a second deciduous tooth from Barranco León and claimed it to be "the oldest human fossil in Europe" (1, title), stating that a previous human molar from the same site (BL5-0) had "no clear anatomical resolution" (2) and more likely belonged to a Hippopotamus antiquus deciduous tooth, based solely on the observation that $H$. antiquus is an abundant species in this layer. In addition, they suggest that the fossil was found out of stratigraphic context. In this contribution we propose a new interpretation of both finds after supplying information on their stratigraphic location and anatomical data from deciduous hippo teeth.

\section{Stratigraphic Context}

BL5-0 comes from a fossiliferous bed named BL5 (Arribas and Palmqvist 2002). This bed is $15-30 \mathrm{~cm}$ thick and composed mainly of fine to medium sandstone, including Jurassic marine and Pleistocene lacustrine carbonate pebbles, mammal remains, and a large assemblage of lithic tools (Gibert et al. $1998 b$ ). This bed occurs within a lacustrine sequence and can be followed for more than $300 \mathrm{~m}$ on both sides of Barranco León. It is the product of a lake-level fall that allowed erosion and resedimentation from the marginal area of a shallow lake (fig. 1A). A minimum age of $>1.25 \mathrm{Ma}$ was calculated for this layer considering the stratigraphic distance to a paleomagnetic reversal interpreted as the top of the Olduvai subchron (1.78 Ma; Scott, Gibert, and Gibert 2007). In 1994, A. Arribas discovered a molar fragment after sieving a sediment sample from the BL5 bed (Arribas and Palmqvist 2002). Later, in 1995, J. Gibert opened a quarry on the area of the discovery and initiated the excavation of this fossiliferous layer. New paleontological excavations at BL5 were not permitted by the administration until 1998 when a new team took the control of the site and renamed the fossiliferous bed. As stated by Toro-Moyano et al. (2010, 2013), the level BL D, where they found the tooth BL02-J54-100 in 2002, is also referred to as BL5, so that the two teeth come from the same bed, which is the only one bearing tools and vertebrate fossils at Barranco León.

The spatial and stratigraphic location of BL5-0 was pub- 


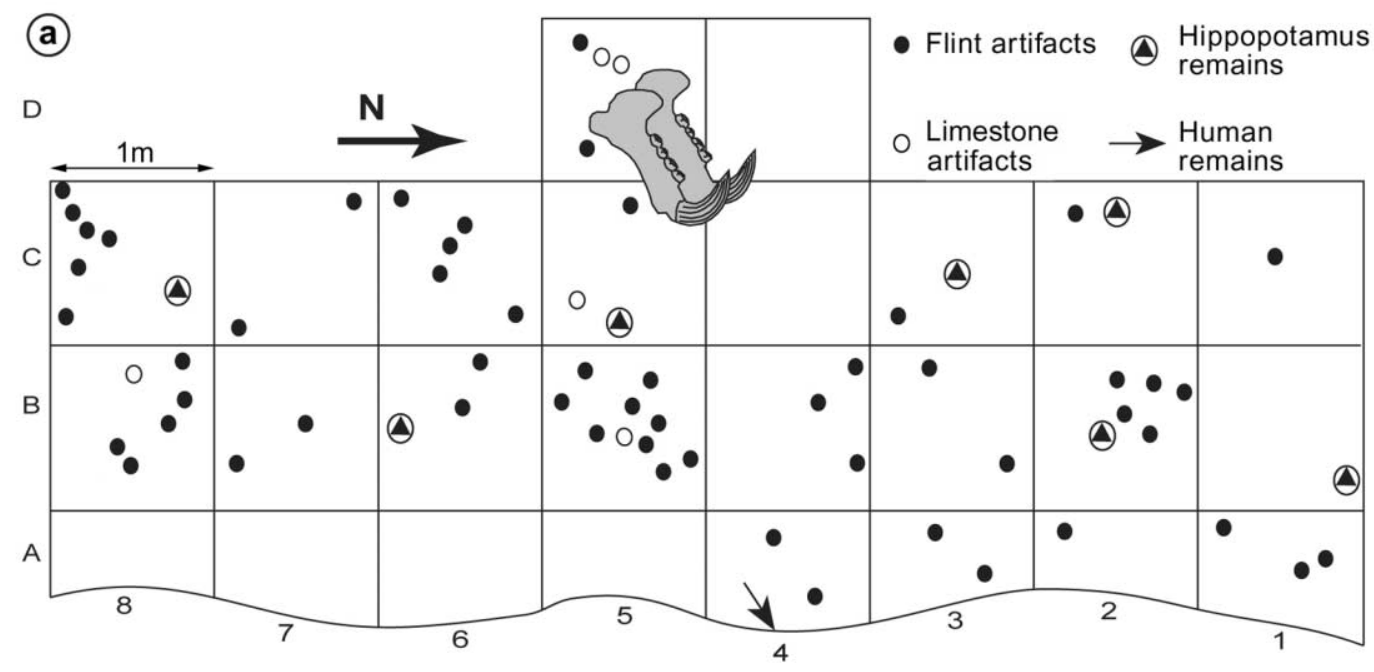

(b)

EXCAVATION PLANS

(c)
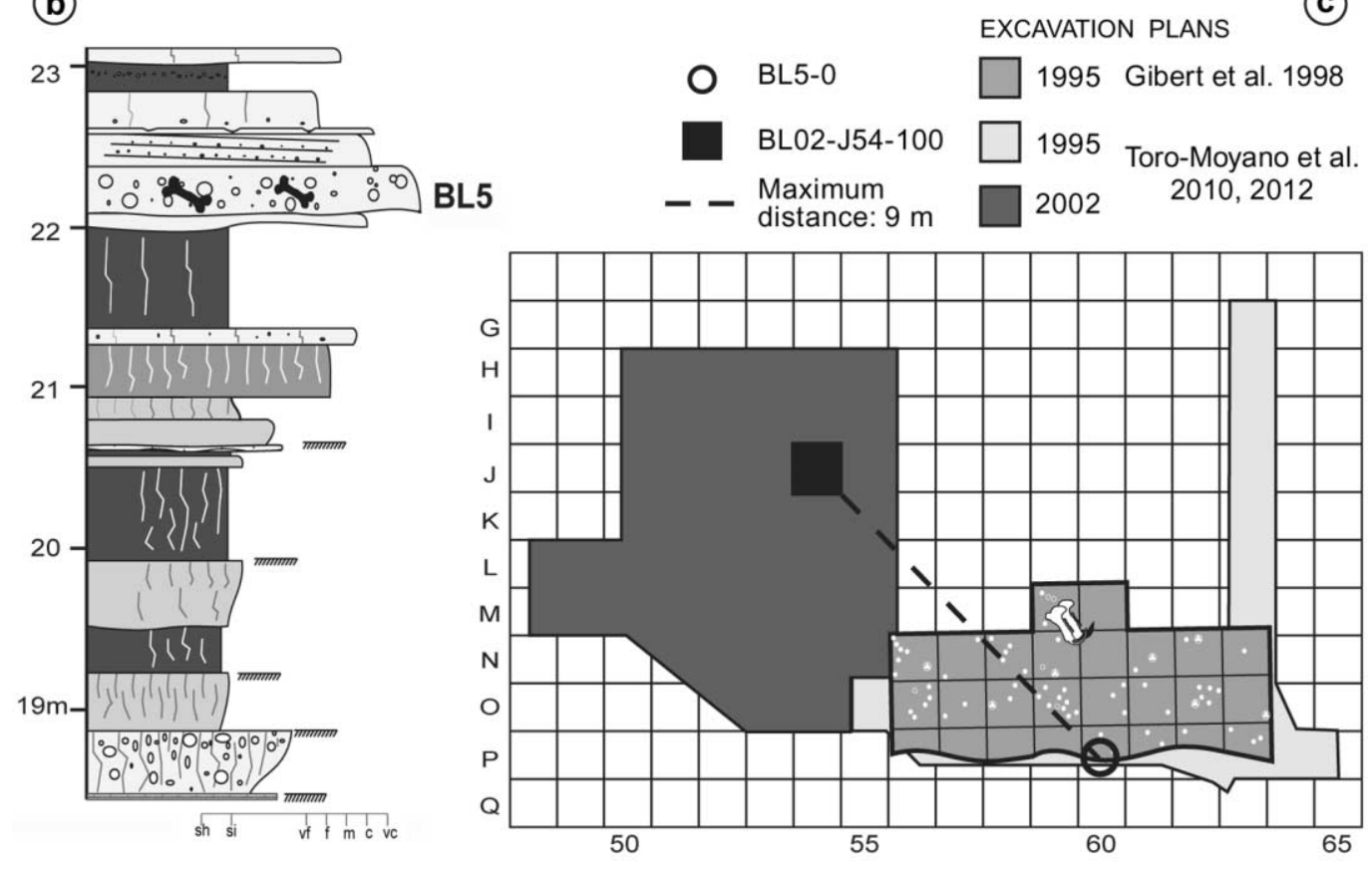

Figure 1. Stratigraphic and archaeological location of BL5-0. (A) Plan of the excavation in the BL-5 bed made in 1995 indicating the distribution of lithic artifacts, adult Hippopotamus remains, and the location of the tooth fragment BL5-0, recovered in 1994 at the edge of square A4. The curved line corresponds to the slope of the ravine. $(B)$ Detail of the Black Detrital Unit (Gibert et al. 1998b) in the Barranco León sedimentary sequence showing the stratigraphic position of BL5 bed where BL5-0 and other finds were collected. In this stratigraphic series, large mammal fossils and lithic tools occur only at bed BL5. (C) Superposition of the excavation plans from 2002 and 1995 (modified from Gibert et al. 1998b and Toro et al. 2010). BL5-0 was found at square A4 of the 1995 plan and falls within the square P60 of later excavations by Toro-Moyano et al. (2010). The lateral distance between BL50 and BL02-J54-100 was less than $9 \mathrm{~m}$. Squares: $1 \mathrm{~m}$.

lished in 1998 (figs. 3b and 4 in Gibert et al. 1998b), and its discovery and initial study were described in detail in Arribas and Palmqvist (2002). A superposition of the excavation plans from 1995 (Gibert et al. 1998b) and 2002 (Toro-Moyano et al. 2010) shows that the two teeth were found less than $9 \mathrm{~m}$ apart from each other (fig. $1 A, C$ ).

\section{Archaeological Context}

The site of Barranco León has archaeological relevance; five lithic artifacts were initially reported from the outcropping bed BL-5 (Gibert et al. 1992). The first systematic excavation in 1995 revealed a mandible of Hippopotamus surrounded by 


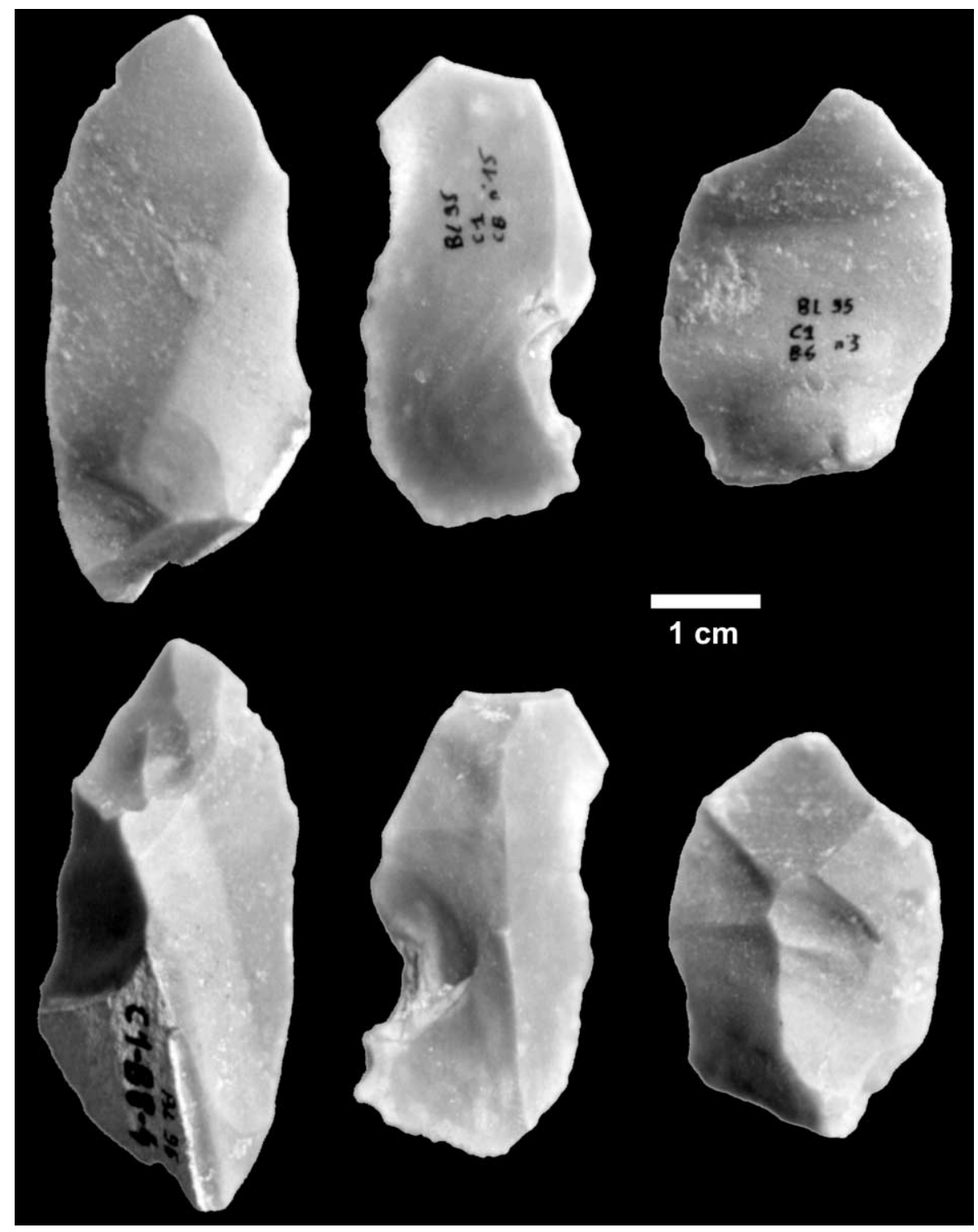

Figure 2. Examples of Oldowan technology from the BL5 site. These flint flakes were unburied during 1995 field season a short distance from the BL5-0 tooth fragment location. The figure shows views of opposite faces of three flakes made with grey Jurassic flint. Scale: centimeters.

more than a hundred lithic artifacts: 114 of flint, 1 of quartzite, and 1 of Jurassic limestone. The tools were associated with early Pleistocene fauna: Castillomys cf. crusafonti, Mimomys sp., Allophaiomys pliocaenicus, Equus granatensis, and Hippopotamus antiquus. The flint cores and flakes are small (range: $20-61 \mathrm{~mm}$; mean: $40.7 \mathrm{~mm}$ ); the butts have a very variable morphology, and the flakes are not usually cortical. Chopper-cores of flint and limestone are also present in BL5 (Gibert et al. 1998b). Subsequent excavations increased the number of artifacts to $>1,200$ (Toro-Moyano et al. 2013). The source of the flint and limestone was the Jurassic from Umbría and Periate ranges, where marine limestones are locally re- placed by chert. Blocks of quality flint (up to $10 \mathrm{~cm}$ ) are found in alluvial fan deposits down in the valley, only $2 \mathrm{~km}$ southeast of the site. The origin of the quartzite should be found in Miocene fluvial deposits outcropping $8 \mathrm{~km}$ from the site, where quartzite pebbles occur. The tools represent a lithic technology with a very simple chaîne opératoire, lacking any sign of bifacial flaking technique; accordingly it can be compared to the Oldowan (Gibert et al. 1998b; see fig. 2). The presence in the same bed of cores and flakes associated with remains of large fauna suggests that the tools were occasionally produced on the site and used to recover the available resources. 


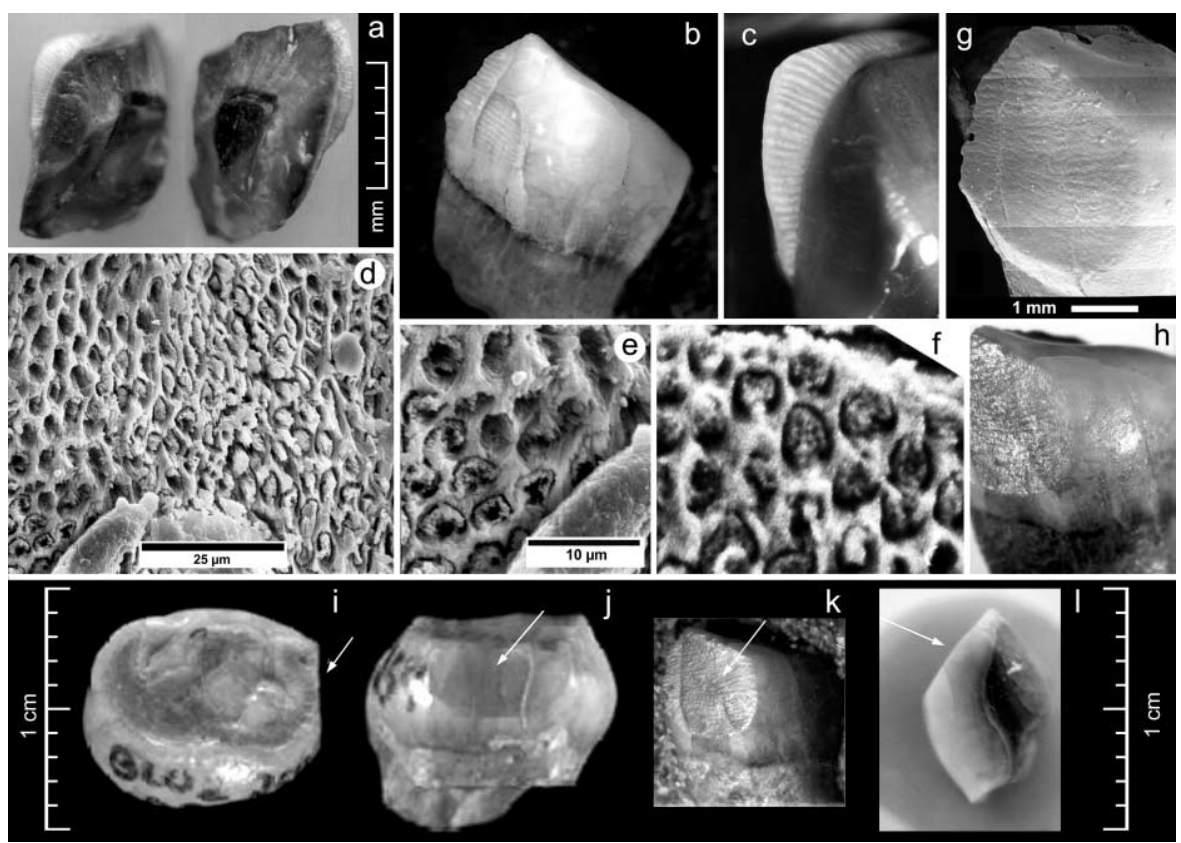

Figure 3. Morphological and enamel features of BL5-0. (A) Fractured face of enamel; note the reduced pulpar cavity. (B) Mesiolingual view of the crown and root in polarized light to show striae of Retzius and Hunter-Schreger bands. (C) Polarized-light photograph showing the parallel Hunter-Schreger bands. ( $D-F)$ SEM photographs showing the enamel prisms pattern of type $3 \mathrm{~b}$ of Boyde (1964). ( $G-H)$ Optical and SEM photographs of the insterstitial contact facet. (I-L) Comparison of BL02-J54-100 (I, J) and BL5$0(K, L)$, at the same scale, showing the similar interstitial contact facets (arrows). ( $I, J)$ Occlusal and mesial view of BL02-J54-100; $(K, L)$ Mesiolingual and nearly occlusal views of BL5-0. Images from BL02-J54-100 reproduced from Toro-Moyano et al. (2013) with permission from Elsevier.
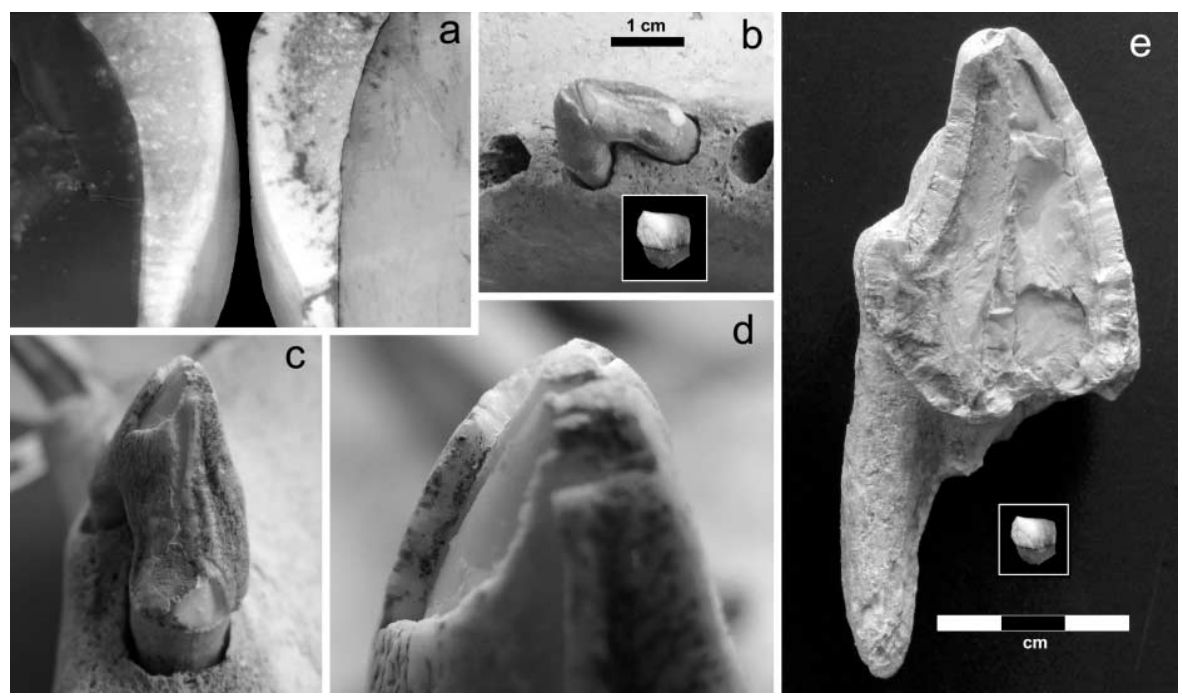

Figure 4. Comparison of BL5-0 enamel with human and hippo enamel. (A) Comparison of enamel thickness of BL5-0 (left) with a modern human molar (right). Note the similar increase in thickness from the cervix to the crown. $(B-D)$ Enamel thickness in a deciduous $\mathrm{mm}_{2}$ of recent Hippopotamus amphibius (MZB-91-0214, 4-5 months old, Age Group I of Laws 1968). (B) Lingual view with BL5-0 at the same scale. $(C-D)$ Mesial view and detail showing the constant thickness of enamel from the cervix to the crown and the reduced thickness at the cusp. (E) BL5-0 compared at the same scale with a broken adult tooth of H. antiquus from Venta Micena (MNCN19273). Note the large and constant thickness of the enamel in H. antiquus. 


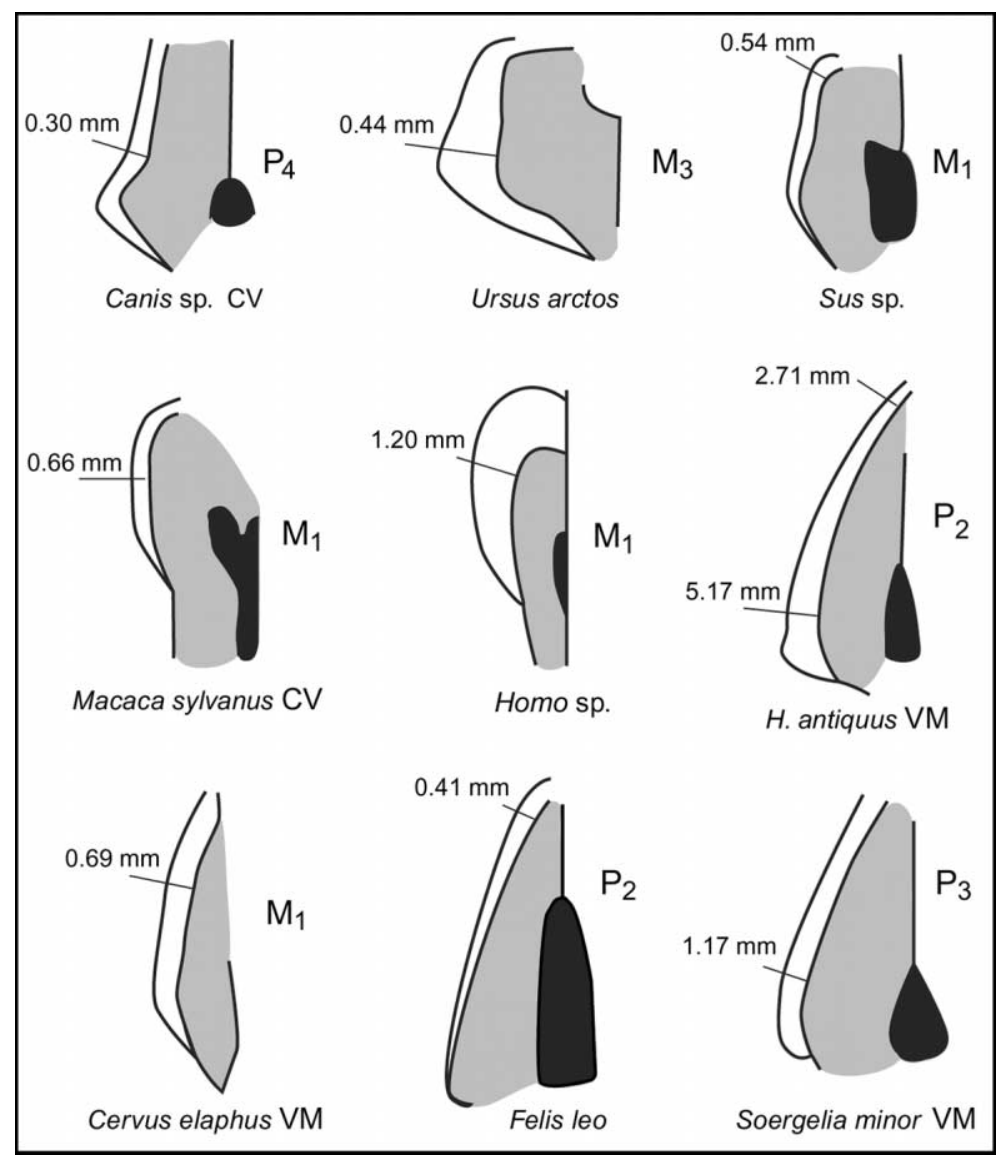

Figure 5. Differences in enamel distribution and maximum thickness for different medium-sized mammals, Homo sp., and Hippopotamus antiquus from Venta Micena (modified from Gibert et al. 1999, not to scale). Both the distribution of the enamel and the enamel thickness differentiate BL5-0 from hippos and other studied mammals. CV: Cueva Victoria; VM: Venta Micena.

\section{The Molar Fragment BL5-0}

BL5-0 is a deciduous human molar fragment found in the BL-5 bed. Only mesial parts of the crown and root remained after an ancient buccolingual fracture. It is heavily worn, exposing the dentine on the occlusal surface, and has an interstitial contact facet. The crown height on the mesial face is $4.6 \mathrm{~mm}$, the length of the broken root is $2.9 \mathrm{~mm}$, and the maximum enamel thickness is $1.2 \mathrm{~mm}$ (figs. $3 A-C, G, H-L$ ). It was assigned to an early Homo based on common anatomical features with Homo, including patterns on the microstructure of the enamel (Gibert et al. 1999; see figs. 3C, E, F and 4). Additionally, an anatomical study was performed, based on enamel microstructure, distribution, and thickness, that differentiates BL5-0 from medium-size large mammals present at the Early Pleistocene sites of Orce (Gibert et al. 1999). The study analyzed enamel from Homo sp., Canis sp., Ursus sp., Sus sp., Macaca sylvanus, Cervus elaphus, Felis leo, and Soergelia minor, but did not consider hippos because of the large difference in size. Here we incorporate into this previous study the enamel of Hippopotamus antiquus from
Venta Micena, which shows an opposite pattern in the enamel distribution (decreasing thickness toward the crown) than in humans (increasing thickness toward the crown; fig. 5).

\section{Previous Work}

After the discovery, Arribas performed a comparative study and rejected the possibility that the tooth belonged to a nonhuman herbivorous or carnivorous mammal. He also undertook a comparative study of the tooth fragment with homologous sections of the upper and lower molariform teeth of omnivorous species (suids, ursids, and hominids), and observed that BL5-0 was analogous to the lower molars of Homo sapiens (Arribas and Palmqvist 2002:68). In consultation, Bermúdez de Castro agreed with a tentative human deciduous molar assignment (Arribas and Palmqvist 2002:68).

The final assignment of BL5-0 to an early Homo was based on the study of the microstructure of the enamel along the fracture surface, a character that plays a central role in interpreting fossil hominin taxonomy (e.g., Lacruz et al. 2008).

This study shows the following human characteristics in 

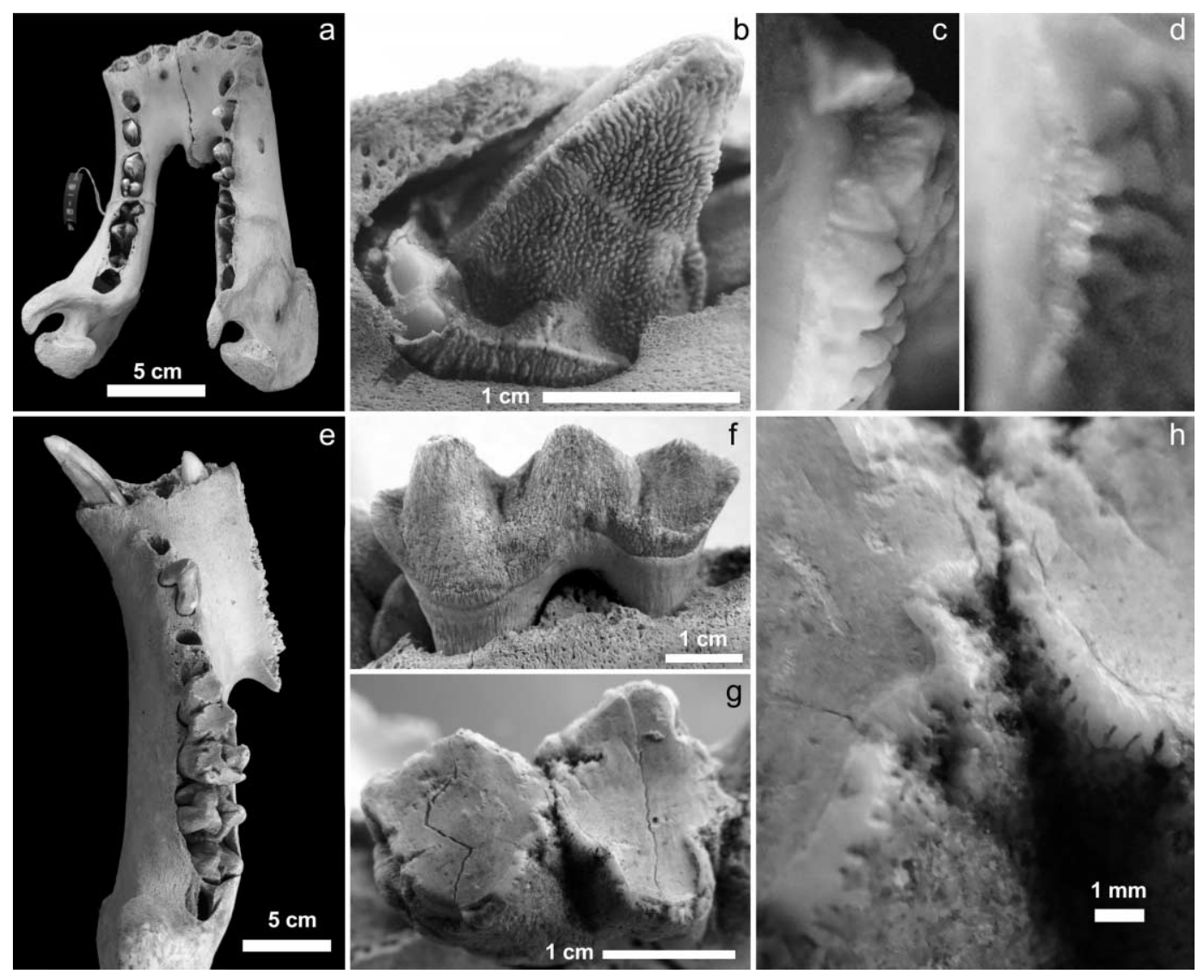

Figure 6. Morphology of deciduous teeth of recent juvenile Hippopotamus amphibius from the Museu de Zoologia of Barcelona (MZB). (A-D) Individual MZB-91-0214, 4-5 months old. (A) Mandible with deciduous premolars $\mathrm{dp}_{2}$ and $\mathrm{dp}_{3}, \mathrm{dp}_{4}$ protruding above bone level, and alveolus of $\mathrm{dm}_{1}$ open (Age Group I of Laws 1968). (B) Detail of right $\mathrm{dp}_{4}$ showing the well-developed cingulum and the rugose enamel surface. $(C-D)$ Details of the enamel in the cusp of the right $\mathrm{dp}_{3}(C)$ and left $\mathrm{dp}_{3}(D)$, showing the rugose surface of the enamel. $(E-H)$ Individual MZB-82-7007, about 1 year old. (E) Left hemimandible with wear evident on all three cusps of $\mathrm{dp}_{4}, \mathrm{M}_{1}$ exposed above bone and alveolus of $\mathrm{dm}_{2}$ open (Age Group III of Laws 1968). ( $F-H$ ) Worn left $\mathrm{dp}_{4}$ showing its large size, and the rugose enamel surface.

BL5-0 (figs. $3 A-L$ and $4 A$ ): the angle of the stria of Retzius $\left(30^{\circ}\right)$ and the Hunter-Schreger bands $\left(80^{\circ}\right)$, the lateral enamel thickness $(1.2 \mathrm{~mm})$, the position of the last imbricate stria, the enamel prism pattern of type $3 \mathrm{~b}$ or "keyhole" defined by Boyde (1964), the increased enamel thickness from the cervix to the crown, and the presence of perikymata (figs. $3 D-F$ and $4 A)$.

\section{Comparison with Hippo Deciduous Teeth and with Human Tooth BL02-J54-100}

Ignoring the enamel characters of BL5-0 provided by Gibert et al. (1999), Toro-Moyano et al. (2013:2) claimed that BL50 "has no clear anatomical resolution" and it is more likely to belong to a $H$. antiquus deciduous tooth, based solely on the observation that $H$. antiquus is an abundant species in this site. Toro-Moyano et al. (2013:2) claimed erroneously that the enamel thickness of BL5-0 "is clearly thinner than in human teeth." The lateral enamel thickness in the molars of adult early Homo varies from 1.2 to $2.1 \mathrm{~mm}$ (Beynon and Wood 1986), the lateral enamel thickness in the lower M1 of extant Homo from 0.96 to 2.19 (Mahoney 2010), and lateral thickness of $\mathrm{dm} 1$ and $\mathrm{dm} 2$ in extant Homo from 0.32 to 1.27 $\mathrm{mm}$ (Mahoney 2010). Therefore, the thickness of the enamel of BL5-0, $1.2 \mathrm{~mm}$, falls within human variability (figs. 3 and 4).

Toro-Moyano et al. (2013:2) then assert: "More specifically, the bunodont teeth of hippos show a relatively thick enamel layer that matches the anatomy of BL5-0 tooth fragment" without showing any picture or measurements. To clarify this point, we compared BL5-0 with deciduous molars of the recent $H$. amphibius, considering that the molar teeth in hippopotamids are very conservative (Coryndon 1977).

Differences between BL5-0 and Hippopotamus teeth. The differences between BL5-0 and Hippopotamus teeth can be summarized as follows: 


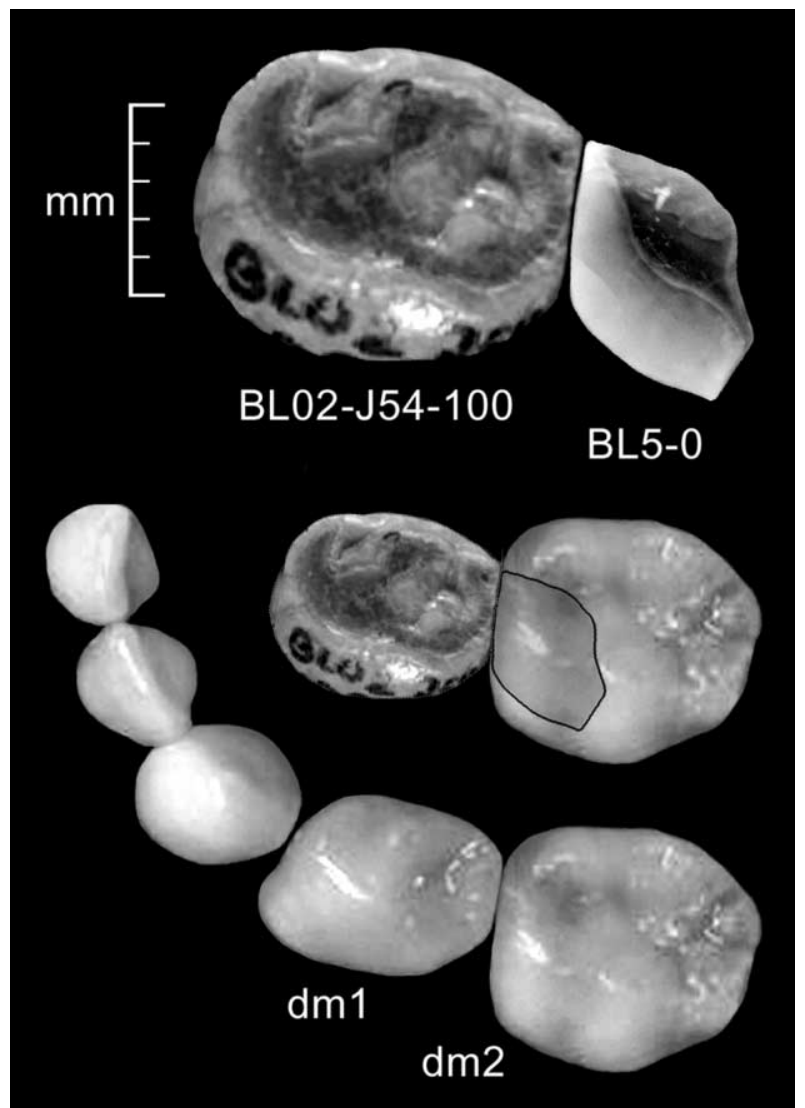

Figure 7. Teeth from Barranco León site compared with Homo sapiens lower left deciduous teeth. BL02-J54-100 would correspond to a left dm1 and BL5-0 to a proximal fragment of a left $\mathrm{dm} 2$, possibly from the same individual. Image from BL02-J54100 reproduced from Toro-Moyano et al. (2013) with permission from Elsevier.

1. In Hippopotamus the enamel is thick and very rugose throughout the tooth surface (e.g., Boisserie 2005; Pavlakis 1990; see figs. $4 C-E$ and $6 B-H)$, whereas in BL5-0 and humans it is completely smooth (fig. 3).

2. The thickness of the Hippopotamus enamel is uniform from the cervix to the crown, whereas in BL5-0 the thickness increases in this direction. Furthermore, in Hippopotamus the enamel is thinner over the cusps than elsewhere (Lucas et al. 2008), whereas in humans the enamel is much thicker over the cusps as in BL5-0 (figs. 3A-C, 4C-E, and 5).

3. Deciduous teeth of Hippopotamus do not have perikymata.

4. Deciduous teeth of Hippopotamus have a cingulum at the base of the crown (fig. 6B) that is absent in BL5-0.

5. The large dimensions of deciduous teeth of Hippopotamus do not permit an anatomical comparison with BL5-0.

Any of these features alone is enough to invalidate the comparison of BL5-0 with Hippopotamus, and all of them together clearly discard the assignment of BL5-0 to this genus.
Comparison between BL5-0 and human specimen BL02-J54100. BL5-0 was described as a possible upper left adult molar based on the heavily worn occlusal surface and the presence of part of the root (Gibert et al. 1999). New observations on BL5-0 and the comparison with specimen BL02-J54-100 revealed that it may be also a deciduous tooth with a pulp cavity similar to that in BL02-J54-100, as was previously suggested by Bermúdez de Castro in 1994 (Arribas and Palmqvist 2002: 68).

In addition, BL5-0 has an interstitial contact facet strikingly similar to the one in BL02-J54-100 (figs. 3G-L and 7).

Common characteristics in BL02-J54-100 and BL5-0 include:

1. Both are heavily worn on the occlusal surface, category 5 of Molnar (1971).

2. In both cases, the roots are practically missing due to resorption. The root length preserved in BL02-J54-100 is 3.1 $\mathrm{mm}$ (estimated from the photos in Toro-Moyano et al. 2013), and $2.9 \mathrm{~mm}$ in BL5-0.

3. Both fossils have a nearly identical interstitial contact facet (figs. 3G-L and 7). In both teeth, these facets are very marked and produce an almost flat interstitial teeth wall with a U-shape.

4. Their size is very similar. The height of the crown in BL02-J54-100 is about $4.4 \mathrm{~mm}$ (estimated from the photos in Toro-Moyano et al. 2013) and $4.6 \mathrm{~mm}$ in BL5-0.

The comparison between BL5-0 and the newly discovered tooth BL02-J54-100 indicates that BL5-0 has a thicker enamel $(1.2 \mathrm{~mm})$. Considering that $\mathrm{dm} 2$ has a thicker enamel than $\mathrm{dm} 1$ (0.62-1.27 and $0.32-0.88 \mathrm{~mm}$, respectively; Mahoney 2010), BL5-0 (1.2 mm) would be better classified as a $\mathrm{dm} 2$. Because of its fragmentary character, it is difficult to precisely locate its position, but possibly BL5-0 corresponds to the mesial part of a left $\mathrm{dm} 2$ (because $\mathrm{dm} 2$ are the last tooth, the distal part lacks interstitial contact facets).

Therefore, it is possible that the two teeth, BL5-0 and BL02J54-100, belonged to the same individual, being contiguous teeth sharing an interstitial contact facet (fig. 7).

\section{Conclusion}

BL02-J54-100 and BL5-0 are both deciduous human teeth from the same site; they were located in the same layer at a maximum distance of $9 \mathrm{~m}$ from each other. They have the same degree of wear and similar morphology and size, with virtually the same crown height and root length, and with the same degree of root resorption. Both teeth have a very similar interstitial contact facet affecting the enamel. The thickness of the enamel of BL5-0 fits better with a dm2 than with a dm1 like BL02-J54-100. The interstitial wear facet would indicate that BL5-0 corresponds to the mesial part of a left $\mathrm{dm} 2$.

Taken together, these observations lead to the conclusion that both teeth might possibly have belonged to the same individual; they could possibly be contiguous teeth, in contact 
through their wear facet. If so, they probably would correspond to the disarticulation of a dead individual, not being shed ante-mortem as interpreted for BL02-J54-100 by ToroMoyano et al. (2013). Given this new interpretation, the possibility of finding more human remains at the site increases.

\section{Acknowledgments}

This paper is a contribution to the Grup de Investigació Consolidat Geologia Sedimentària (2014 SGR 251 and the Ramón y Cajal Program of the Spanish government). The authors thank the staff of the Museu de Zoologia de Barcelona and the Museo Nacional de Ciencias Naturales for their assistance and to Robert A. Martin for helpful comments on the manuscript. We dedicate this paper to the memory of Dr. Josep Gibert; thanks to his pioneer work, Orce appears in the scientific records.

\section{References Cited}

Aguirre, Emiliano. 2008. Homo hispánico. Madrid: Espasa-Calpe.

Arribas, Alfonso, and Paul Palmqvist. 2002. The first human dispersal to Europe: remarks on the archaeological and palaeoanthropological record from Orce (Guadix-Baza basin, southeastern Spain). Human Evolution 12:55-78.

Beynon, A. David, and Bernard Anthony Wood. 1986. Variations in enamel thickness and structure in east African hominids. American Journal of Physical Anthropology 70:177-193.

Boisserie, Jean-Renaud. 2005. The phylogeny and taxonomy of Hippopotamidae (Mammalia: Artiodactyla): a review based on morphology and cladistic analysis. Zoological Journal of the Linnean Society 143:1-26.

Borja, Concepción, Marcos García-Pacheco, Enrique García-Olivares, Gary Scheuenstuhl, and Jerold Marvin Lowenstein. 1997. Immunospecificity of albumin detected in 1.6 million-year-old fossils from Venta Micena in Orce, Granada, Spain. American Journal of Physical Anthropology 103:433441.

Boyde, Alan. 1964. The structure and development of mammalian enamel. $\mathrm{PhD}$ thesis, University of London.

Campillo, Domènech, Mariana Rovira, José Antonio Sánchez-Sánchez, S. Vila, Josep Gibert, and Lluís Gibert. 2003. Radiographical study of skull fragment of Venta Micena (VM-0) (Orce, Granada Spain). Human Evolution 18:131146.

Campillo, Domènech, María Milagros Cuesta, Elena García-Guixé, Eduardo Chimenos, Laura Devenat, and Joaquim Baxaries. 2006. An occipital crest in an infant cranium from the Roman necròpolis of Francolí (Tarragona, Spain): implications to the interpretation of the Orce skull. Revista Española de Antropología Física 26:93-101.

Coppens, Yves. 1992. Préface. In Presencia humana en el Pleistoceno inferior de Granada y Murcia. Josep Gibert, ed. Pp. 5. Orce, Spain: Museo de Prehistoria Josep Gibert.

Coryndon, Shirley Cameron. 1977. The taxonomy and nomenclature of the Hippopotamidae (Mammalia, Artiodactyla) and a description of two new fossil species. Proceedings of the Koninklijke Nederlandse Akademie van Wetenschappen B80(2):61-88.

Gibert, Josep, Domènech Campillo, Josep Maria Arqués, Enrique GarcíaOlivares, Concepción Borja, and Jerold Marvin Lowenstein. 1998. Hominide status of the Orce cranial fragment reasserted. Journal of Human Evolution 34:203-217.

Gibert, Josep, Lluís Gibert, Sílvia Albadalejo, Francesc Ribot, Florentina Sánchez, and Patxu Gibert. 1999. Molar tooth fragment BL5-O: the oldest human remain found in the Plio-Pleistocene of Orce (Granada province, Spain). Human Evolution 14:3-19.

Gibert, Josep, Lluís Gibert, Carles Ferràndez, Alfredo Iglesias, and Fernando González. 2006. Venta Micena, Barranco León-5 and Fuenten- ueva-3: Three Archaeological Sites in the early Pleistocene Deposits of Orce, south-east Spain. In The human evolution source book. Russell L. Ciochon and John G. Fleagle, eds. Pp. 327-335. Upper Saddle River, NJ: Prentice Hall.

Gibert, Josep, Lluís Gibert, Alfredo Iglesias, and Eudald Maestro. 1998. Two 'Oldowan' assemblages in the Plio-Pleistocene deposits of the Orce region, Southeast Spain. Antiquity 72:17-25.

Gibert, Josep, Alfredo Iglesias, Alfons Maillo, and Luis Gibert. 1992. Industrias líticas en el Pleistoceno Inferior de la región de Orce. In Presencia humana en el Pleistoceno Inferior de Granada y Murcia. Pp. 219-240. Orce, Spain: Museo de Prehistoria.

Gibert, Josep, and Paul Palmqvist. 1995. Fractal analysis of the Orce skull sutures. Journal of Human Evolution 28:561-575.

Gibert, Josep, Francesc Ribot, Carles Ferrández, Bienvenido Martínez, Roxana Caporicci, and Domènech Campillo. 1989a. Anatomical study: comparison of the cranial fragment from Venta Micena (Orce, Spain) with fossil and extant mammals. Human Evolution 4:283-305.

. 1989b. Características diferenciales entre el fragmento de cráneo de Homo sp. de Venta Micena (Orce, Granada) y los équidos. Estudios Geológicos 45:121-138.

Gibert, Josep, Francesc Ribot, Patxu Gibert, and Lluís Gibert. 2006. Obliteration study of lambdatic and obelionic region sutures in ruminant, carnivores and hominids. Estudios Geológicos 62:123-134.

Lacruz, Rodrigo S., M. Christopher Dean, Fernando Ramirez-Rozzi, and Timothy G. Bromage. 2008. Megadontia, striae periodicity and patterns of enamel secretion in Plio-Pleistocene fossil hominins. Journal of Anatomy 213:148-158.

Laws, Richard Maitland. 1968. Dentition and ageing of the hippopotamus. East African Wildlife Journal 6:19-52.

Lowenstein, Jerold Marvin, Concepción Borja, and Enrique García-Olivares. 1999. Species-specific albumin in fossil bones from Orce, Granada. Spain. Human Evolution 14:21-28.

Lucas, Peter, Paul Constantino, Bernard Wood, and Brian Lawn. 2008. Dental enamel as a dietary indicator in mammals. BioEssays 30:374-385.

Mahoney, Patrick. 2010. Two-dimensional patterns of human enamel thickness on deciduous (dm1, dm2) and permanent first (M1) mandibular molars. Archives of Oral Biology 55:115-126.

Martínez-Navarro, Bienvenido. 1996. Similarities between skull fragment VM0 from Orce (Spain) and the Homo erectus holotype from Trinil (Java). Revista Española de Paleontología 1:120-121.

- 2002. The skull of Orce: parietal bones or frontal bones? Journal of Human Evolution 42:265-270.

Molnar, Stephen. 1971. Human tooth wear, tooth function and cultural variability. American Journal of Physical Anthropology 34:175-190.

Moyà, Salvador, and Jordi Agustí. 1989. Una reinterpretación del fragmento craneal de Orce: Equus stenonis Cocchi. In Los restos humanos de Orce $y$ Cueva Victoria. Josep Gibert, Domènech Campillo, and Enrique GarcíaOlivares, eds. Pp. 447-451. Sabadell, Spain: Institut Català de Paleontologia Miquel Crusafont.

Moyà-Solà, Salvador, and Meike Köhler. 1997. The Orce skull: anatomy of a mistake. Journal of Human Evolution 33:91-97.

Palmqvist, Paul, Bienvenido Martínez-Navarro, Isidro Toro, María Patrocinio Espigares, Sergio Ros-Montoya, Vanessa Torregrosa, and Juan A. PérezClaros. 2005. Réévaluation de la presence humaine au Pléistocène inferieur dans le sud de l'Espagne. L'Anthropologie 109:411-450.

Pavlakis, Parissis P. 1990. Plio-Pleistocene Hippopotamidae from the Upper Semliki. In Results from the Semliki research expedition. Noel T. Boaz, ed. Pp. 203-223. Martinsville: Virginia Museum of Natural History Memoir.

Sánchez, Florentina, Josep Gibert, Assumpció Malgosa, Francesc Ribot, Lluís Gibert, and Michael J. Walker. 1999. Insights into the evolution of child growth from lower Pleistocene humeri at Venta Micena (Orce, Granada province, Spain). Human Evolution 14:63-82.

Scott, Gary, and Lluís Gibert. 2009. The oldest hand axes in Europe. Nature 461:83-86.

Scott, Gary, Lluís Gibert, and Josep Gibert. 2007. Magnetostratigraphy of the Orce region (Baza Basin), SE Spain: new chronologies for early Pleistocene faunas and hominid occupation sites. Quaternary Science Reviews 26:415435.

Tobias, Phillip Vallentine. 1998. Commentary on the case for early Pleistocene hominids in south-eastern Spain. Human Evolution 13:91-96.

Toro-Moyano, Isidro, Bienvenido Martínez, María Patrocinio Espigares, and Sergio Ros Montoya. 2010. La excavación arqueológica. In Ocupaciones 
humanas en el Pleistoceno inferior y medio de la Cuenca de Guadix-Baza. Isidro Toro, Bienvenido Martínez-Navarro, and Jordi Agustí, eds. Pp. 924. Granada, Spain: Junta de Andalucía.

Toro-Moyano, Isidro, Bienvenido Martínez-Navarro, Jordi Agustí, Caroline Souday, José María Bermúdez de Castro, María Martinón-Torres, Beatriz
Current Anthropology Volume 56, Number 1, February 2015

Fajardo, et al. 2013. The oldest human fossil in Europe, from Orce (Spain). Journal of Human Evolution 65:1-9.

Torres, Jesús Manuel, Concepción Borja, and Enrique García-Olivares. 2002. Immunoglobulin G in 1.6 million-year-old fossil bones from Venta Micena (Granada, Spain). Journal of Archaeological Science 29:167-175. 